Proceedings of the Second Annual Forestry Symposium 1996: Management and Sustainable Utilization of Forest Resources, Sri Lanka, 6-7 December 1996. (Eds. Amarasekera, HS. Ranasinghe, D M S HK and Finlayson, W. Published by Department of Forestry and Environmental Science, University of Sri Jayewardenepura, Sri Lanka (1998)

\title{
VEGETATIVE PROPAGATION OF TEAK BY TISSUE CULTURE
}

\author{
D.M.S.H.K. Ranasinghe ${ }^{1}$ and G.M. Berlyn ${ }^{2}$ \\ ${ }^{1}$ Department of Forestry and Envirommental Science, University of Sri Jayewardenepura \\ ${ }^{2}$ School of Forestry and Environmental Studies, \\ Yale University, New Haven, USA
}

\begin{abstract}
Multiple shoot formation was induced from excised seedling nodal explants. On Murashige \& Stoog medium supplemented with IBA (0.3 mg/litre) and BAP' (I mg/litre) about 2-5 shoots were obtained within 10-15 days from each explant, in a growth chamber at $25^{\circ} \mathrm{C}$ ' with a light source of 100 lux for 16 hours/day. When the shoots produced in vitro were subcultured to multiply on fresh medium of the same constituents, they yielded a crop of shoots within 3 weeks. Shoot explants and tender leaf discs taken from plantlets grown in vitro and also from potted seedlings 3-4 months old from the growth chamber were also tried for adventitious shoot production without much success. Callus formation was also tried with these shoot explants. Isolated shoots were rooted by culturing on the following media for 10 davs: (a) half-strength MSS medium devoid of growth regulators, or (b) half-strength MS medium supplemented with indolebutryic acid at (i) $0.3 \mathrm{mg}$ /litre, (ii) $1 \mathrm{mg} /$ litre, (iii) $2 \mathrm{mg} /$ litre, or (iv) $3 \mathrm{mg} /$ litre. They were then transferred to hormone-free half-strength MS medium. Roots were initiated in about $80 \%$ of the shoots in treatments $b$ (i) and $b$ (ii) while other treatments produced no rooting. However, when transferred to hormone-free medium, shoots that had been growing in treatments $b$ (iii) and $b$ (iv) also rooted within 7 days. The plantlets were hardened and transferred to pots, which were placed first in the growth chamber at $25^{\circ} \mathrm{C}$ with 100 lux for 16 hours/day and subsequently transferred to the greenhouse.
\end{abstract}

\section{Introduction}

Teak (Tectona grandis) is an important forest tree, highly valued for its wood. It is indigenous to Burma, central and south India, and Thailand. It is one of the main exotic species for plantations in the tropics (Evans, 1982) and has been planted on a large scale in Sri Lanka. 
It has a worldwide reputation as a high quality timber on account of its remarkable physical and mechanical properties. particularly shape retention, durability. resistance to fungi and chemicals (Wealth of India. 1976). Most important is its natural resistance to termites. due to the presence of sesquiterpenes (Maslckar, 1981).

Teak thrives best and reaches its largest dimensions in a fairly moist tropical climate (Wealth of India. 1976). It can withstand drought very well, but is sensitive to frost (Maslekar. 1981). Areas with a normal annual rainfall of $1250-2500 \mathrm{~mm}$ and a marked dry season of 3-5 months are favourable for its development (Wealth of India, 1976). It can withstand an absolute minimum shade temperature of $2^{\circ} \mathrm{C}$. The mean annual temperature which suits it best is between 23 and $28^{\circ} \mathrm{C}$ (Watt. 1972). It generally prefers rich soil with good drainage and a dry subsoil. It thrives well in the fertile lower slopes of the hills where the soil is deep. It is intolerant of shallow soils.

It is generally propagated from seeds. Various methods of vegetative propagation have been used. such as budding and grafting (Mahmood \& Somasundaram, 1975), rooting of cuttings (Lahiri, 1974) and rooting of buds cut from stock stumps raised in polypots (Mahmood et al.. 1976). For large-scale plantations stump plants are often used: they are prepared from seedlings $30-40 \mathrm{~cm}$ long. about one year old

The recent trend to using genetically improved forest trees emphasizes the need for the identification and multiplication of superior genotypes. The source trees have certain desirable traits and are referred to as "élite" or "plus" trees. Elite teak trees have been identified in several forests in Sri Lanka. They were selected on the basis of total height. clean bole height. crown height. crown diameter, cylindrical unfluted tnunk. and selfpruning habit.

The conventional melhods of vegetative propagation have limitations. They are slow and time consuming. Teak being a cross-pollinated species. progeny raised from seed show wide variation. It also has an irregular seed-bearing habit and the production of seed tends to be much lower than the requirement (Lee \& Rao. 1981). Viability is poor and is affected by the season when the seed is collected and by the storage conditions (Department of Forestry. New Guinea. 1962). The seeds are enclosed in hard coats and show very poor germination rates in spite of various pretreatments (Dabral \& Amin. 1975: Dabral. 1976: Davidson \& Fairlamb. 1976: Joshi \& Kelkar, 1971). These characteristics have become a major problem in large-scale plantating. In the face of the rising demand for teak planting stock. the traditional tree improvement and multiplication programmes are not productive enough.

A rapid means of producing a large number of plants for afforestation is offered by micropropagation. It has been estimated by Gupta et al. (1979) that by subculture. 500 viable plants can be obtaince from a single bud of a mature plant. or 3000 plants from a single secdling. in one year. The main objective of the present investigation was to develop a routinc method for cloning teak by tissue culture. 


\section{Materials and methods}

In the following account, note that the growth chamber was in each case set at $25^{\circ} \mathrm{C}$, with light at 100 lux for 16 hours day

\section{Preparation of seeds}

Dried teak fruits were used, collected from selected plus trees in plantations in Sri Lanka. They were opened by a nut cracker. The sceds were washed in running tap water at room temperature for 2 hours. They were then placed in a petri dish and dipped in $70 \%$ ethanol for 3 minutes, then in benzalkonium chloride (a bacteriocide) at 720 $\mu \mathrm{l} /$ litre for 50 seconds. The treated seeds were then immersed in $20 \%$ Chlorax with a few drops ( 3 drops in $100 \mathrm{ml}$ ) of Tween 20 (a wetting agent) for 20 minutes and washed in 3 changes of sterile distilled water for 2 minutes cach. In preliminary tests, dipping seeds in 10\% and $50 \%$ Chlorax for 10,20 and 30 minutes was also tried but $20 \%$ for 20 minutes proved to be the most successful.

\section{Germination of seed}

The surface-sterilized seeds were placed individually in the following media:

- half strength Murashige \& Skoog (MS) devoid of growth regulators

- full strength MS devoid of growth regulators

- full strength MS + $3 \mathrm{mg} /$ litre 6-benzylaminopurine (BAP)

- full strength MS + $5 \mathrm{mg} /$ litre BAP

- full strength $\mathrm{MS}+0.3 \mathrm{mg} /$ litre indole 3-butyric acid (IBA) + $1 \mathrm{mg} /$ litre BAP

All the media contained $2 \%$ sucrose and 1\% Difco Bacto Agar. The $\mathrm{pH}$ was adjusted to 5.8. The culture tubes were sealed with tape and incubated in a growth chamber. Half of the seeds were given light and half were kept in the dark. 


\section{Multiplication of material: adventitious shoot formation}

After the seedlings raised in vitro had produced about 2-3 nodes, which usually took about 23 days, the shoot segments with apical or axillary buds were excised and cultured on the following media:

- MS + 0.1 mg/litre kinctin + 0.1 mg/litre BAP

- $\mathrm{MS}+0.3 \mathrm{mg} / \mathrm{litre}$ IBA $+1 \mathrm{mg} / \mathrm{litre}$ BAP

- MS + 1 mg/litre kinetin + $1 \mathrm{mg} /$ litre BAP

- MS + $0.15 \mathrm{mg} /$ litre kinctin + $0.15 \mathrm{mg} / \mathrm{litre} \mathrm{BAP}$

All the cultures were incubated in a growth chamber. The treatments were replicated.

Explants were also taken from potted seedlings 3-4 months old raised in the greenhouse. Shoot segments were used that had an apical or an axillary bud and tender leaf parts were also used. They were sterilized with $10 \%$ Chlorax for 10 minutes with 3 subsequent washings of stcrile distilled water for 2 minutes each and were placed in MS medium supplemented with $0.3 \mathrm{mg} / \mathrm{litre}$ IBA and $1 \mathrm{mg} / \mathrm{litre}$ BAP.

\section{Initiation of callus}

Seedlings germinated in vitro, and potted seedlings 3-4 months old from the greenhouse were also used for callus formation. In this trial, explants with an apical or axillary bud were sterilized in $10 \%$ Chlorax for 10 minutes with 3 subsequent washings of sterile distilled water for 2 minutes each and placed in the following media in a growth chamber:

- MS + 0. + BAP + 2 2-4-D (2-4-dichlorophenol, an auxin)

- $\mathrm{MS}+0.4 \mathrm{BAP}+12-4-\mathrm{D}$

- $\mathrm{MS}+3 \mathrm{BAP}+12-4-\mathrm{D}$

- $\mathrm{MS}+3 \mathrm{BAP}+22-4-\mathrm{D}$

When callus was formed. it was chopped in small pieces and placed in bud-growing medium (half strength $\mathrm{MS}+0.1 \% \mathrm{BAP}+4 \%$ sucrose). 
Shoots about $4-5 \mathrm{~cm}$ height, with about 3-4 pairs of leaves, werc placed on the following rooting media:

- half strength MS devoid of growth regulators

- half strength MS + $0.3 \mathrm{mg} /$ litre IBA

- half strength MS + $1 \mathrm{mg} /$ litre IBA

- half strength MS + 2 mg/litre IBA

- half strength MS + 3 mg/litre IBA

The culture tubes were placed in the growth chamber.

\section{Acclimatization}

Rooted plantlets from the culture tubes were planted in pots with Promix soil mixture (top soil:vermiculite:perlite:sand:peat moss at 2:1:1:1:1) which was soaked with sterile distilled water and then with a $1 \%$ solution of Roots. To retain moisture the pots were covered with glass beakers, which were gradually removed in order to harden off the plantlets. After about 20-30 days the plantlets were planted put into larger pots and transferred to the greenhouse.

\section{Results and discussion}

\section{Germination}

With the sterilization procedure described above, a $60 \%$ germination rate was obtained with $20 \%$ contamination. This is acceptable for tropical species, from which it is difficult to obtain sterile cultures (Miedzybrozka, 1995). Seeds immersed in $10 \%$ Chlorax were more contaminated (35\%) than those in 20\% Chlorax. Immersion in $50 \%$ Chlorax scemed to be lethal.

The germination rate on half strength MS medium was $60 \%$, while that on full strength MS was less. at $50 \%$. This observation may be compared with that of Miedzybrodzka, 1995. who reported only $28 \%$ seed germination of teak on full strength MS medium as opposed to $60 \%$ on half strength. Seeds did not germinate in MS media with $3 \mathrm{mg} / \mathrm{litre}$ or $5 \mathrm{mg} / \mathrm{litre}$ BAP. They did germinate in the MS medium with $0.3 \mathrm{mg} /$ litre IBA and 1 $\mathrm{mg} / \mathrm{litre}$ BAP, but the growth and development of the seedlings were inferior to those grown on hormone-frec media, and root systems were not properly formed.

\section{Multiplication of material: adventitious shoot formation}

Explants from seedlings grown on half strength MS medium devoid of growth regulators did not respond with shoot multiplication when placed on MS media supplemented only with cytokinins. However, when $0.3 \mathrm{mg} / \mathrm{litre}$ IBA and $1 \mathrm{mg} / \mathrm{litre}$ 
BAP were added. about 2-5 adventitious shoots developed in 10-15 days from nodal stem segmen:s. No callus formation was observed in this medium and shoot development appeared to arise from preformed axillary buds. The shoots grew rapidly and were $40-50 \mathrm{~cm}$ long in 30 days.

Although the addition of cytokinins alone did not encourage shoot proliferation in the present experiment, it has donc so successfully in some other studies. Gupta et al. (1980) in a trial in India on shoot multiplication of teak reported that kinetin and BAP added at the rate of $0.1 \mathrm{mg} /$ litre each to the MS medium produced 2-3 adventitious shoots in 15-20 days from the shoot apex, nodal stem segment and the hypocotyl segment containing the cotyledons. They reported greater additions of cytokinins to be lethal: all explants died in the treatment with kinetin or BAP at the rate of $5 \mathrm{mg} / \mathrm{litre}$. Concentrations of BAP between 0.1 and $2 \mathrm{mg} /$ litre produced 2 shoots from the hypocotyl segment containing the cotyledons, but only the shoot tip had elongated.

In India Devi et al. (1994) made observations on the rapid cloning of teak by multiple shoot production in-vitro, that contradict the above findings. They reported that MS medium with $1 \mathrm{mg} / \mathrm{litre}$ Kinetin and $5 \mathrm{mg} / \mathrm{litre}$ BAP was the most suitable medium as it produced about 5-6 axillary shoots within 7 days. For continucd shool elongation these shoots were transferred to MS medium supplemented with $1 \mathrm{mg} / \mathrm{litre}$ each of Kinctin and BAP. In their studies on shoot multiplication of tcak in India, Mascarenhas et al. (1987) reported that semi-solid MS medium, supplemented with Kinctin $(0.15 \mathrm{mg} / \mathrm{litre})$ and BAP (0.15 mg/litre) were the best for shoot multiplication: about 3-4 shoots had developed from each seedling explant, except for those with apical buds, within 20-25 days.

In the experiments reported here, shoot segments and tender leaf segments taken from 3-4 month old scedlings grown in the greenhouse or from the secdlings grown in vitro did not show bud growth when placed in multiplication medium (MS medium +0.3 $\mathrm{mg} /$ litre IBA $+1 \mathrm{mg} / \mathrm{litre}$ BAP). However, contradictory evidence can be obtained from other workers. In India, Mascarenhas et al. (1987) had been successful in getting bud sprouting in MS :nedium sipplemented with $0.15 \mathrm{mg} / \mathrm{litre}$ each of Kinctin and BAP. Similar results were reported from India by Gupta et al. (1980) from experiments on axillary and terminal vegetative teak buds collected from 100-year-old elite trees, in which shoot clongation was apparent after 3-4 weeks. More experimentation is required in this area.

Although in many studies, (Gupta el al., 1980; Miedzybrodska, 1990; etc.) browning of the shoot-multiplication medium was observed, due to the oxidation of phenolics from the tissues, it was not seen in the present study.

\section{Rooting of adventitious shoots}

On half strength MS medium devoid of growth regulators. explants from the multiplication medium formed roots directly. This observation is endorsed by Apichart (personnel communication) from his work on in-vitro cloning of teak in Thailand in 
1995. In the present study. roots were initiated on $80 \%$ of the shoots within 10 days in half strength MS medium supplemented with $0.3 \mathrm{mg} /$ litre or $1 \mathrm{mg} / \mathrm{litre}$ IBA. Root initiation was not observed in treatments with half strength MS supplemented with either 2 or $3 \mathrm{mg} / \mathrm{litre}$ IBA. However, when the explants were transferred to half strength MS medium devoid of hormones, about $70 \%$ of the explants from the media with 2 or 3 mg/litre IBA produced healthy roots within 7 days. Those from the other treatments, on which roots were already initiated, showed healthy root development.

These observations are in agreement with those of Gupta et al. (1980), who reported $80 \%$ root initiation in shoot explants within 3-4 weeks in a low-salt White's medium containing IAA, IBA and IPA at $0.1 \mathrm{mg} / \mathrm{litre}$ each. However, the shoot explants then had to be transferred to hormone-free White's medium as the high auxin concentrations inhibit root development. They also reported that the optimum period for treatment of shoots in an auxin medium could be reduced to 6 days before transfer to an auxin-frec medium for healthy root devclopment. Similar observations were reported by Devi et al. (1994) on teak in India.

To improve the rooting response, the salt concentration of MS medium was reduced to "half strength". The successful results confirm the findings of Purohit et al. (1996) on micropropagation of Wrightia tomentosa in India, in which they observed considerable improvement in rooting of shoots on quarter strength MS salt medium supplemented with $0.5 \mathrm{mg} /$ litre IBA.

The cfficacy of relatively low concentrations of IBA in the rooting of explants observed in the present study was also confirmed by the observations of the above study on IIrightia tomentosa, where rooting was observed on all media within 7 days, with IBA concentrations ranging from 0.1 to $2 \mathrm{mg} / \mathrm{litre}$. The maximum rooting response (45\%) was obtained with $0.5 \mathrm{mg} /$ litre IBA.

\section{Conclusions}

About 2-5 adventitious shoots were induced within 10-15 days from excised seedling explants of teak grown im vitro on MS medium supplemented with $0.3 \mathrm{mg} / \mathrm{litre}$ IBA and $1 \mathrm{mg} /$ litre BAP. in a growth chamber at $25^{\circ} \mathrm{C}$ with a light source of 100 lux for 16 hours/day:

When these adventitious shoots were about $4-5 \mathrm{~cm}$ tall. with $3-4$ pairs of leaves. about $80 \%$ root initiation was obtained within 10 days by placing them in the same growth chamber conditions. on half strength MS medium supplemented with cither 0.3 or I mg/litre IBA, They then showed healthy root development when placed on half strength MS medium devoid of growth regulators. Shoots placed on half strength MS medium supplemented with 2 or $3 \mathrm{mg} /$ litre IBA did not show root initiation but roots were induced within 7 days when they were subsequently placed on half strength MS medium devoid of growth regulators. 


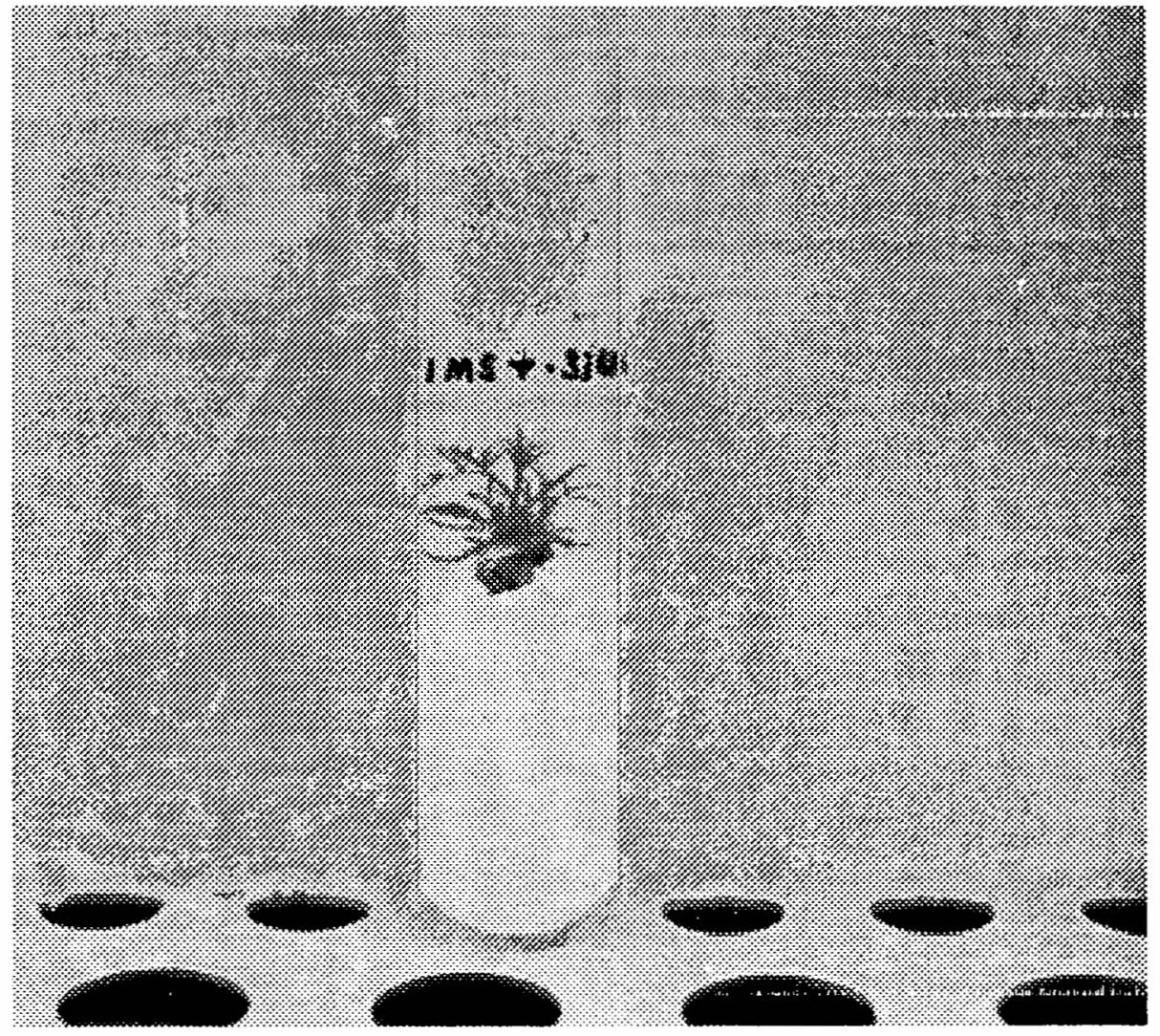

Figure 1: Multiplication of shoots on MS medium $+0.3 \mathrm{mg} / \mathrm{litre}$ IBA and $1 \mathrm{mg} / \mathrm{litre}$ BAP

\section{Acknowledgements}

The Center for the International Exchange of Scholars, USA, which awarded a Fullbright Fellowship. and the School of Forestry and Environmental Studics of Yale University are sincerely thanked for enabling this research to be pursued

\section{References}

Dabral, S.L. and Amin, P.W. (1975). Poor fruit formation in tcak in Chanda Forests of Maharashtra. Indian Forester 101. 616-619.

Dabral, S.L. (1976). Extraction of teak seeds from fruits. their storage and germination. Indian Forester 102. 650-658. 


\section{References}

Dabral. S.L. and Amin. P.W. (1975). Poor fruit formation in teak in Chanda Forests of Maharashtra. Indian Forester 101, 616-619.

Dabral. S.L. (1976). Extraction of teak seeds from fnits, their storage and germination. Indian Forester 102. 65(1-658.

Davidson. J. and Fairlamb. J. (1976). (iermination of teak seeds - Preliminarv evidence of a chemical germination inhibitor. In seed Problems, Proceedings of the 2nd International IUFRO Symposium on Physiology of Seed Germination. Japan.

Department of Forestry. New Guinea (1962). Storage of teak sceds. Forestry Ahstracts 23,1879

Devi, Y.S.. Mukherjec. B.B. and Gupta. S. (1994). Rapid cloning of élite teak (Tectona grandis) by in vitro multiple shoot production. Indian Journal of Experimental Biologv 32 (9) 668-671.

Evans, J. (1982). Plamtation forestry in the tropics. Oxford University Press.

Gupta, P.K., Nadgir, A.L., Mascarenhas, A.1. and Jagannahan, V. (1980). Tissue culture of forest trees: clonal multiplication of Tectona grandis (teak) by tissue culture. Plant Sicience Letters 17, 259-268.

Joshi. M.D. Kelkar. S.P. (1971). Germination of seed in dry teak (Tectona grandis) (1) Preliminary studies in fruit development and secd dormancy. Indian Forester 97. $210-212$.

Lahiri. A.K. (1974). Preliminary study on rooting of green wood cutting of teak. Indian Forester 100, 559-560).

Lec. S.K. and Rao. A.N. (1981). In vitro plantlet development in tropical trees Callophyllum inophyllum and Eugenia grandis. In: Tissue culture of economically important plants (Ed. A.N. Rao). Singapore. COSTED. Pp.185190 .

Mahmood Hussain, A.M. and Somasundaram, T.R. (1975). Scions on stumps - an innovation in the vegetative propagation of teak (Tectona grandis). South Forest Rangers College Magazine 51, 1-8.

Maslekar. A.R. (1981), Forester's companion. India. Jugal Kishore and Company.

Miedzybrodska, M. (1995). Report on Micropropagation Consultancy Visit to the Forestry Unit, University of Sri Jayewardenepura. UK, Fountain Renewable Resources Ltd.

Mascarenhas, A.F., Kendurker, S.V., Gupta, P.K., Khuspe, S.S. and Agrawal, D.C. (1987). Teak, cell and tissue culture in forestry, case histories, gvmnosperms, angiosperms and palms. In Forestry Sciences (Eds. J.M. Bonga and D.J. Durzan). The Netherlands, Martinus Nijhoff Publishers.

Oka. A.F. (1976). Teak nursery practices in Maharashtra State. Nagpur, India. Research and Educa-tion Circle.

Purohit, S.D., Kukda. G. and Tak, K. (1996). Micropropagation of Wrightia tomentosa (Roxb.) Roem. et Schult. Journal of Sustainable Forestry 3 (4) 25-35.

Watt. G. (1972). Dictionary of cconomic products of India. Vol VI. Part IV. Delhi, India. Periodical Experts.

Wealth of India (1976). Vol X. India, Information Directorate, CSIR 